\title{
Community-Based Homestay Management in the Village Tourism of Tete Batu, Lombok
}

\author{
Yogi Birrul Walid Sugandi ${ }^{1}$, Syamsul Alam Paturusi ${ }^{2}$, \\ Agung Suryawan Wiranatha ${ }^{2}$ \\ ${ }^{1}$ Master Program in Tourism, Udayana University \\ ${ }^{2}$ Centre of Excellence in Tourism, Udayana University \\ Corresponding Author: ybws1992@gmail.com
}

\section{ARTICLE INFO \\ Received \\ 2 September 2020 \\ Accepted \\ 18 September 2020 \\ Available online \\ 30 September 2020}

\begin{abstract}
The dynamics of homestay development in the village tourism in Lombok is very rapid after the launching of 99 village tourisms by the West Nusa Tenggara Government. Homestay is one of the ways to get benefits of tourism by local community. Otherwise, the operation of homestays, especially in Tete Batu has impacted on three main problems: the welfare distribution is not easy to achieve, conflicts of interest, homestay programs are not well organized. This research aimed to produce community-based homestay management strategies. This study used a qualitative method with SWOT analysis. Data collection was done by observation, interviews, documentation, literature studies, and FGDs. There were 17 informants deliberately chosen. The results showed that the position of the homestay was in strong internal and external conditions. The right grand strategies to apply are market penetration, market development, product management and development. The combination strategy results are as follows: establishing and strengthening of homestay institutions, making integrated tour packages, optimizing online promotional content, procuring digital system, improving environmentally friendly villages, increasing the qualied human resources, maintaining the authenticity of nature and traditions, creating variety of new tourist attractions, increasing community empowerment, forming the synergy of pentahelix.
\end{abstract}

Keywords: Homestay Management, Village tourism, Community-Based Tourism

\section{INTRODUCTION}

In the development of Lombok tourism, the West Nusa Tenggara
Provincial Government has launched a priority alternative tourism development program based on the environmental, social, and cultural conservation as well as 
improvement of the local economy through the 99 village tourism program. This is based on the impact of mass tourism which has a significant impact on global climate change, socio-cultural degradation, ecosystem damage, and social disparities between rich and poor. Therefore, it is hoped that the negative impacts of tourism can be reduced through alternative tourism (Haywood, 1988; Murphy 1985).

One of the strategies is to prioritize the principle of sustainable tourism through a community-based tourism (CBT) approach in village tourisms. In principle, CBT optimizes community integration in the environment, socio-culture, and local economy (Noor and Pratiwi, 2016: 179). This idea is attempted to involve community participation in organizing local tourism products (Simmons, 1994: 98).

Following up on the orientation of quality tourism development, the West Nusa Tenggara Provincial Government has encouraged many parties to explore the potential of village tourisms. The number of village tourisms divided from each district is as follows: 10 in Bima, 9 in Dompu, 4 in Bima City, 4 in Mataram City, 13 in West Lombok, 16 in Central Lombok, 18 in East Lombok, 8 in North Lombok , 9 in Sumbawa, 8 in West Sumbawa. East Lombok dominates the spread of the village tourisms.
In terms of homestay development, East Lombok has also experienced a rapid increase every year. In 2015, there were 28 homestays, then in 2019 there were 133 homestays (East Lombok Tourism Office, 2019). Apart from the good infrastructure conditions of the road to Lombok tourist destinations, the cost of building a homestay is also quite affordable for local people. The presence of a homestay also provides a multiplier effect. The Ministry of Tourism's program is prioritizing the construction of 100,000 homestays in all Indonesian village tourisms. It is hoped that the role of the community in the homestay can mobilize collective awareness in developing sustainable village tourisms. (Ministry of Tourism Press Release 2016).

Today, the increasing number of homestay developments and tourism development priorities in the Tete Batu area have increased significantly. From 7 homestays in 2014 to 32 homestays in 2019 (East Lombok Tourism Office, 2019). Some of the tourism actors are motivated to plan a homestay development. As a result, almost every hamlet has a homestay. This can be the main value in providing an authentic experience of living and doing activities with the community with a variety of beautiful landscapes, plantations, agriculture, livestock, hills, waterfalls, culture, arts and traditions that are still inherent in people's daily lives which e-ISSN: 2407-392X. p-ISSN: 2541-0857 
become a very valuable combination for tourists and increase the length of stay.

However, the existence of homestays in Tete Batu does not have a management body such as an organization or association. The homestay management system seems to run independently without being managed together to achieve common goals. The impact of this causes at least three main indications, namely the distribution of community welfare is not evenly distributed, there are frequent conflicts of interest in the arrangement of homestays, the program of village tourism activities is not well managed. On the other hand, the homestay management community has the same expectations, namely to create prosperous, sustainable, and developed local resources in terms of tourism. Seeing the condition of this inequality, it is considered important to plan community-based homestay management which can then bring together the goals of the Tete Batu community so far.

Thus, the participation of the Tete Batu community does not only obtain efficiency and distribution of material evenly, but how the community itself can share knowledge and transform the learning process for the development of self-potential (Cornell: 1997: 250). In this case Haywood (1988: 106) describes community participation as a process of involvement of all http://ojs.unud.ac.id/index.php/eot stakeholders, local governments, NGOs, and local residents, as well as planners, so that tourism development decisions can be formulated carefully and wisely. Empowerment and community involvement then play an active role in planning, managing and evaluating. Therefore, it is easier for the community to understand the processes and proper governance.

\section{LITERATURE REVIEW}

It is explained in the book ASEAN Homestay Standard, 2016 that homestay is an accommodation provided by local people as an alternative tourism activity where tourists stay in local people's homes to experience daily life with the host as well as existing tourist attractions. Its main value is a means of participating in the activities of local people so that they can witness firsthand the cultural values and daily traditions as well as exploring the natural beauty and tourist attractions.

Therefore, there are nine criteria for a homestay, namely: 1. Availability of homestay providers, 2. Facilities, 3. Activities, 4. Management, 5. Location (accessibility), 6. Hygiene and cleanliness, 7. Safety and security, 8. Marketing and promotion, 9. Principles of sustainability. In the context of a village tourism, Inskeep (1991) in the Tourism Research and 
Development Center (2011) explains that village tourism is a tourism facility that allows visitors to live in or near the village. The village tourism in question is a place that is administratively classified as a village tourism that is legalized by the local government where there are variants of tourist attractions offered to visitors either directly or through homestays provided by local people. Thus, the role of the homestay in the village tourism is very integrated. Realizing community-based homestays management, which also requires the concept of tourism and community-based tourism.

These two concepts link the interaction and interactions of people in tourism activities that take into account the economic, socio cultural and environmental impacts on local communities (UNEP \& UNWTO, 2005). This approach is triggered by the negative impact of a destination that has not been able to protect its natural resource ecosystem from the pressure of mass tourism growth (Neto, 2003: 4).

Suansri (2003) also suggests that CBT can be a tool for realizing sustainable tourism. Relevant with Isnaini (2007) in Hadiwijoyo (2012), namely strengthening the capacity of local community organizations in tourism. The principles of development are: 1) Supporting and promoting community tourism, 2) involving community members, 3) http://ojs.unud.ac.id/index.php/eot
Improving quality of life, 4) Ensuring environmental sustainability, Maintaining culture, 6) Developing crosscultural learning, 7) Distributing profits fairly. Yaman \& Mohd (2004) in Nurhidayati (2012) explain several keys to sustainable tourism development with a Community-Based Tourism approach, namely: 1) The existence of government support, 2) Participation from stakeholders, 3) Fair distribution of benefits, 4) Efficient use of resources local, 5) Strengthening local institutions.

Next is management theory, according to Terry (2000: 9), management is a process or framework that involves guiding or directing a group of people towards organizational goals with the POAC (Planning, Organizing, Actuating, Controlling) function. Planning: preparation of steps, preparing all needs, calculating constraints, and formulating the form of implementation. Organizing: harmonizing groups, bringing interests together, exploiting potential in a particular direction. Actuating: stimulating members to carry out their respective duties and roles. Controlling: activities to monitor, prove and ensure all activities that have been planned, organized, ordered and conditioned before being implemented according to specific targets or objectives. 


\section{RESEARCH METHODS}

This research uses a qualitative approach. The primary data of the study were data obtained through direct interviews and FGDs with informants who were selected deliberately (purposive sampling). Some of the informants consisted of homestay providers, tourism awareness groups, Tete Batu tourist figures, cultural figures, tour guides, porters, village heads, village-owned enterprises, academics, and the head of the East Lombok Tourism Office.

Secondary research data is data obtained from written sources in the form of previous research results, relevant books and texts, government report data, researchers also collect internet data from reliable sources in the form of documents, pictures, newspapers. The data analysis techniques are: 1) Descriptive analysis, which is processing data obtained from research sources and then reducing it by making an abstraction to make a summary and selecting the data so that it can be adjusted, then identifying and categorizing. The next step is to draw conclusions, namely presenting the data in a simple form according to the criteria and classification, providing verification of the data and information obtained. 2) SWOT matrix analysis that produces an alternative strategy of homestay management in Tete Batu Village.

\section{RESULTS AND DISCUSSION}

Tete Batu Village is one of the villages that were expanded from its main village, namely Kotaraja in 1969 in the District of Sikur, located in the north directly adjacent to the Mount Rinjani National Park (TNGR) area with an altitude of 700/9000 masl. Its area is 8,095.8 hectares with a population of 8,596 people consisting of 4,009 men and 4,587 women. Administratively, Tete Batu consists of 6 (six) areas, namely: Tete Batu Hamlet, Lingkung Leuk, Lingkung Deye, Orang Gerisak, Kembang Sri and Presak. The source of people's livelihood is farming and gardening with commodities such as rice, corn, durian, jackfruit, avocado, mangosteen, chocolate, mahogany, banana, cloves, coffee and coconut.

The topography of this village is formed by a canyon that extends like a contour of the land, which presents green and lush panoramas of terraced rice fields. This village also offers beautiful natural scenery, namely steep hills that form waterfalls including Jeruk Manis waterfall, Durian Indah waterfall, Sarang Wallet waterfall, and Ulem-Ulem valley. Different attractions such as the monkey forest, culinary local cuisine, panoramic walk. 
Finally, the southern Rinjani hiking route through Timba Nuh.

\section{Current Homestay Management}

Referring to 9 aspects of the Asean Homestay Standard, namely: 1) Homestay provider. The homestay does not always have to be one or the same roof of the house with the owner. At least located in the same yard with the owner. There are 21 homestays in Tete Batu. Eight homestays have made business permits. Meanwhile, they do not have a document permit for environmental management (UPL) at all. 2) Homestay facilities. Selection of the type of equipment for bed cover, toilet area, clean water, insect protection, mosquitoes are effectively conditioned. The environment is clean and tidy, the hygiene of drinks and food is very important. Then almost all types of homestays have the same building materials. 3) Homestay activities / programs. All homestays offer a panoramic walk as an integrated attraction. 4) Homestay management.

People have the type of workers who do not have many plans and programs and they prefer to be ready to work, so that the technical guidelines for the management system do not exist. 5) Location. some homestays can only be reached by footpaths that can only be passed by motorbikes and then on foot. The role of google tracks and google map is http://ojs.unud.ac.id/index.php/eot very helpful for homestay providers so that they are easily digitized. 6) Hygiene and cleanliness. The host provides hand washing equipment, boiled drinking water. Piles of leftover food are mostly disposed of in trash cans and then treated by the pokdarwis, the tourism empowerment group. Cleanliness of the room, air circulation has been fulfilled.

7) Safety and security. Safetyrelated medical equipment is not considered important in every homestay. Currently, the community health center is still working together to overcome this situation. 8) Promotion and marketing. Most homestay sales are through the booking.com site. Other sites such as Air BNB, Traveloka, Agoda, Titan, and Last Oyo. Meanwhile, the tour operators have their own website / blog to sell tour packages in Tete Batu. 9) Sustainable principles. First, local economic sustainability. Homestay providers have been able to empower the community, at least in the vicinity. Starting from supplying vegetables, participating in cooking, youths becoming tour guides, renting camping equipment, and shuttle services for guests. This triggers the implementation of economic turnover. Second, environmental sustainability. Tourists also take part in reforestation, Most of the community has used environmentally friendly materials, 
including reducing plastic. The homestay building was built semi-permanently following the discourse of residential spatial regulation. Third, socio-cultural sustainability. To preserve community activities, usually separately the results of event revenue are given to the customary event procession. The farming tradition has not benefited directly from tourism.

\section{Carrying Capacity of Homestays}

The highest number of accommodations in East Lombok Regency is in Sikur District with 46 accommodations with 296 rooms which are dominated by Tete Batu including the types of hotels and villas. The Tete Batu area is divided into two, namely Tete Batu Induk where the research was conducted, then Tete Batu Selatan. The neighboring villages are Kembang Kuning and Jeruk Manis. All these tourist villages have the same tourism products and market segments. Thus, the calculation of carrying capacity must be from the total number of lodgings. During 12 months / 1 year, it is divided into 4 occupancy classifications. Low season (December - February), middle (March May). In both seasons a quarter of the 21 homestays were occupied. Meanwhile, in high season (June, September, October, December) $60 \%$ of the homestays are occupied with the average visit rate. Finally, during the peak season (Julyhttp://ojs.unud.ac.id/index.php/eot
August), almost all homestay rooms are fully occupied.

\section{Assistance for new homestays}

The orientation of the assistance carried out is to bring in guests more quickly and guests who visit can also get good service so that the image of the Tete Batu tourist destination is still felt positively by tourists. Thus, new homestay entrepreneurs receive technical guidance from their relatives, and pokdarwis, the Tete Batu tourism village empowerment group. The form of assistance is in the form of service (hospitality) both in terms of entertaining guests, communicating, and arranging rooms for rooms as well as providing the right food and beverage menu. However, assistance is still lacking in terms of digitizing and operating an online system for homestays and integrated tour packages.

\section{The homestay venture capital}

Many of the people around Rinjani are still classified as poor, seen from the average economic income of people below 1 million Rupiah per month, it is found that there are 5 main aspects of financial support in homestay development. First, installments of income from cultivated fields and rice fields that are more than 1 year. The second is the savings from being a tour guide. Third, by selling cows from 
livestock. Fourth, by becoming a migrant worker in Malaysia. Fifth, some people get financial assistance from guests who have stayed overnight and by borrowing money from the bank. The cost spent to build a homestay with 2 rooms and 1 small restaurant for guests can reach more than 100 million rupiah.

\section{Social Impact}

Social jealousy often occurs, especially when there is assistance from both the government and the private sector, both physical and financial assistance. Concentration of aid sometimes dominates in certain places. Meanwhile, other regions within one area did not receive attention so that the distribution of aid was not evenly distributed. In the absence of definite management from the homestay provider, there is a conflict of interest when assisting homestay facilities to people. Often the assistance is directed only to certain groups, not to other people who are entitled to receive assistance. So this is very vulnerable to disharmony among tourism actors. In addition, there was a change in the perspective of farmers. Farmers already think of money as a logical consequence of commercialization because of the involvement of tourists in their ricefields to take pictures.

\section{Internal and external factors that influence homestay management in Tete Batu Tourism Village}

Internal factors that influence the management of the Tete Batu homestay are the strengths and weaknesses, namely having a natural rural atmosphere, friendly local people, doing activities in the fields with farmers, strategic location in the southern area of Mount Rinjani, having a variety of tourist attractions. While the weaknesses: weak wifi and telecommunications networks, the cleanliness of the surrounding environment is not maintained, the noise of community activities, language barriers between people and tourists, homestays do not have governance guidelines. From the sum of item weights $x$ rating, the total value is 3.3 . While opportunities for external factors are: the rapid development of the digital booking platform, the development of the Mandalika special economic zone, the increase in tourism events in Lombok, Tete Batu is located in the Rinjani Geopark Area, there is strong support from the central and provincial governments regarding assistance with homestay facilities. However, the threats are that the competition for homestays in new tourist villages in the southern Rinjani Circle is increasing. The total score on external factors is 3.08 . 
The next stage, based on the total score of internal-external factors, can be seen from the position of the homestay to implement a strategy that is appropriate to the current conditions by entering the total score into the internal-external matrix. The results of this score indicate that the condition of the homestay is in cell 1 , which is a strong and high internal-external condition. In this position, the management of a homestay in Tete Batu Tourism Village can implement a market concentration strategy, market development, management and product development.

- Market penetration

- Market development

- $\quad$ Product development Grow and Build

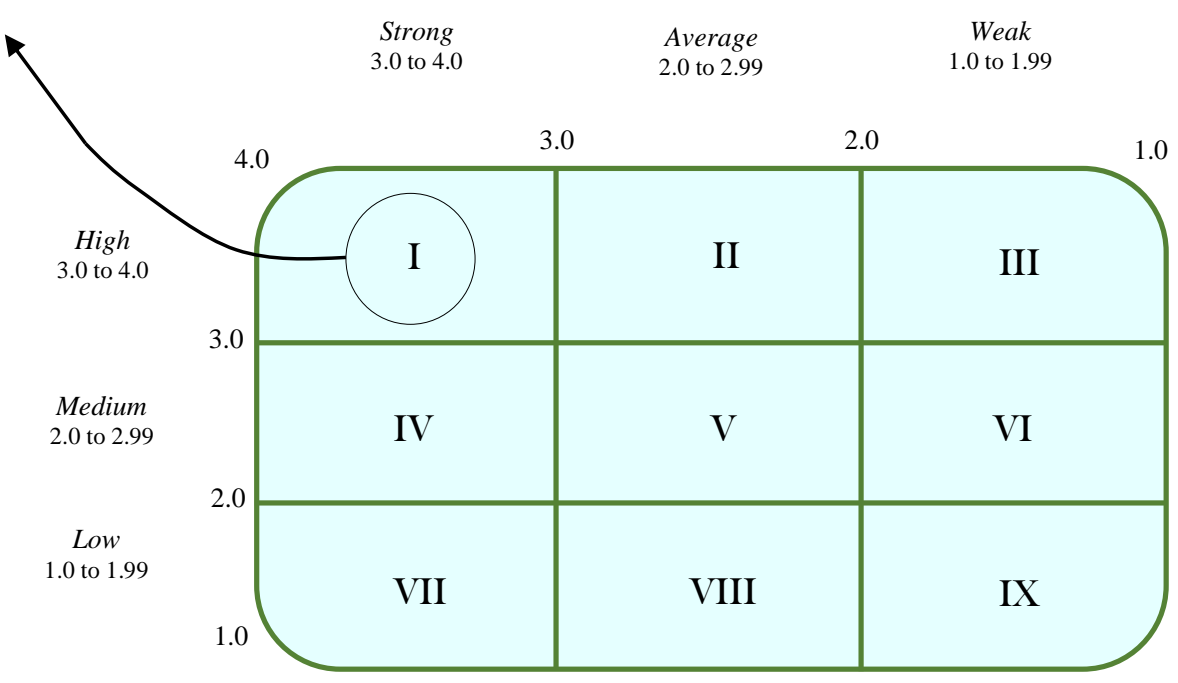

Figure 1. Matrix of Internal-External Factors (Source: David, 2004)

\section{Management Strategy}

Identification of internal and external factors can create four main strategies, namely SO (StrengthOpportunity), WO (WeaknessOpportunity), ST (Strength-Threat), WT (Weakness-Threat) which can be seen in detail in the following table: 
Table 1. SWOT Analysis of Community Based Homestay Management in Tete Batu Village

\begin{tabular}{|c|c|c|}
\hline & Strengths $(\mathrm{S})$ & Weaknesses (W) \\
\hline External & $\begin{array}{l}\text { 1. It has a beautiful, } \\
\text { cool, natural and } \\
\text { authentic rural } \\
\text { atmosphere } \\
\text { 2. Hospitality of hosts } \\
\text { and local people } \\
\text { 3. Activities with } \\
\text { farmers and going } \\
\text { around the rice fields } \\
\text { 4. Strategic location on } \\
\text { the border of Mount } \\
\text { Rinjani } \\
\text { 5. Having a variety of } \\
\text { tourist attraction }\end{array}$ & $\begin{array}{l}\text { 1. Weak WiFi and } \\
\text { telecommunication } \\
\text { networks } \\
\text { 2. The cleanliness of the } \\
\text { surrounding } \\
\text { environment is not } \\
\text { maintained } \\
\text { 3. Noise of local people } \\
\text { activities } \\
\text { 4. Language barrier } \\
\text { between the people and } \\
\text { tourists } \\
\text { 5. Homestays do not have } \\
\text { definite governance } \\
\text { guidelines }\end{array}$ \\
\hline Opportunities $(\mathrm{O})$ & SO Strategies & WO Strategies \\
\hline $\begin{array}{l}\text { 1. The rapid development of } \\
\text { the digital booking } \\
\text { platforms } \\
\text { 2. Development of the } \\
\text { Mandalika special } \\
\text { economic zone } \\
\text { 3. The increasing number of } \\
\text { tourism events in Lombok } \\
\text { 4. Tete Batu is included into } \\
\text { the Rinjani Geopark Area } \\
\text { 5. there is strong support } \\
\text { from the central and } \\
\text { provincial governments } \\
\text { regarding assistance with } \\
\text { homestay facilities }\end{array}$ & $\begin{array}{l}\text { Strategies that use } \\
\text { strength to take advantage } \\
\text { of opportunities } \\
\text { 1. Improving the quality } \\
\text { of homestay facilities } \\
\text { and infrastructure } \\
\text { 2. Establishment and } \\
\text { institutional } \\
\text { strengthening of } \\
\text { tourism } \\
\text { homestays village } \\
\text { 3. Design integrated tour } \\
\text { packages } \\
\text { 4. Optimization } \\
\text { professional of } \\
\text { promotional content } \\
\text { through online media }\end{array}$ & $\begin{array}{l}\text { Strategies that minimize } \\
\text { weaknesses to take } \\
\text { advantage of opportunities } \\
\text { 1. Procurement of digital } \\
\text { system technology } \\
\text { facilities } \\
\text { 2. Improved } \\
\text { environmentally } \\
\text { friendly } \\
\text { management village } \\
\text { 3. Improving the quality of } \\
\text { human resources for } \\
\text { industry players } \\
\text { (homestays) } \\
\text { 4. Making technical } \\
\text { guidelines for homestay } \\
\text { governance to with } \\
\text { integrated tourist } \\
\text { attractions }\end{array}$ \\
\hline Threats $(\mathrm{T})$ & ST Strategies & WT Strategies \\
\hline $\begin{array}{l}\text { 1. The growth of homestays } \\
\text { is increasing } \\
\text { 2. The development of other } \\
\text { new tourism villages in } \\
\text { Lombok }\end{array}$ & $\begin{array}{l}\text { Strategies that use } \\
\text { strengths to overcome } \\
\text { threats } \\
\text { 1. Strengthening the } \\
\text { natural authenticity } \\
\text { and traditions of local } \\
\text { communities as Tete } \\
\text { Batu icons } \\
\text { 2. Improve the quality of } \\
\text { various tourist } \\
\text { attractions }\end{array}$ & $\begin{array}{l}\text { Strategies that minimize } \\
\text { weaknesses and avoid } \\
\text { threats } \\
\text { 1. Increase awareness and } \\
\text { empowerment creativity } \\
\text { 2. Forming and smoothing } \\
\text { pentahelix synergy }\end{array}$ \\
\hline
\end{tabular}


S-O Strategy (StrengthsOpportunities) strategies: improving the quality of homestay facilities and infrastructure, establishing and strengthening tourism village homestay institutions, designing integrated tour packages, optimizing professional promotional content through online media. From all of this it can be elaborated to be well organized so that it can reach the available segments to grab ongoing and future opportunities.

$$
\text { W-O (Weaknesses-Opportunities) }
$$
strategies: procurement of digital technology facilities, improving environmentally friendly village management, improving the quality of homestay human resources, making technical guidelines for homestay governance. All of these aspects can immediately provide specific solutions so that all weaknesses can be resolved properly.

S-T (Strengths-Threats) strategy: strengthen natural authenticity and local traditions as an icon of Tete Batu, increasing the quality of various tourist attractions.

The W-T (Weaknesses-Threats) strategies: increasing awareness and creativity for community empowerment, which is more varied in the context of communities in tourist village areas, forming and smoothing pentahelix http://ojs.unud.ac.id/index.php/eot synergies such as local government, academics, tourism practitioners, local communities, and the media. Be aware of the weaknesses and challenges that will be faced, so collaboration is needed.

\section{Community-based homestay management program}

\section{The management program of the S-O}

\section{Strategies}

a. Increased role of community involvement: dissemination to farming communities for the management of plant variants in order to maintain and organize the area, then income from tourism activities can be distributed to farming communities through: provision of farming facilities, provision of basic assistance, social service donations, micro-business fund assistance, educational scholarships , and others.

b. Strengthening the capacity of the tourism village homestay human resources: initiating the local community to be able to form a Tete Batu homestay association so that they can organize all their needs and increase their respective capacities in an integrated manner.

c. Designing integrated tour packages: creating integrated tour package profiles in the form of digital videos and photos, booklets, flyers both shown in e-ISSN: 2407-392X. p-ISSN: 2541-0857 
online media and provided in the form of booklets at each homestay.

\section{Management program of the $\mathrm{W}-\mathrm{O}$} strategies

a. Procurement of digital system technology facilities: technical guidance for the use and utilization of the internet effectively for the benefit of interaction with guests, reviewing reviews, registering and controlling tourist traffic, cooperation with the Telkom Indihome program for shared wifi.

b. Environmentally friendly village campaign: as a whole the homestay and its surroundings cannot be separated or all are related. The village in general needs to increase programs that use environmentally friendly concepts in terms of tools and cooking materials, saving electricity and water energy, packaging of consumables.

c. Monthly technical evaluation and monitoring of homestay governance: the need to design a homestay program with complete rules and standards that must be met in homestay governance so that physical planning and a series of activities can be well realized in today's homestay growth.
3. The management program of the $S-T$

\section{Strategies}

a. Strengthening natural and traditional authenticity: continuous guidance in destination arrangement and making distinctive attributes of the unique forms of building construction and tourist areas in order to pay attention to the existence of local identities from the character of Tete Batu Village.

b. Improve the quality of the variety of tourist attractions. So far, tourists can only do activities in the morning and during the day. Meanwhile, at night there is no attraction that can be seen and visited. There needs to be an increase in the attractiveness of the homestay such as sasak cultural performances, local theaters, and cultural gala dinners.

\section{The management program of the W-T} Strategies

a. Community empowerment creativity: learn traditional dance, learn art, both traditional art and music, which then becomes a unity performance. This can be an added value that the tourist can do in the future.

b. Collaboration and synergy: making MoUs with local governments, academics, NGOs, village communities and the media. 


\section{CONCLUSIONS AND SUGGESTIONS}

\section{Conclusions}

The current management model, both individual and group homestays in Tete Batu Tourism Village do not have an institutional homestay management unit in the form of an association. There is no short-term and long-term program planning from the homestay manager internally. Especially for technical planning matriculation. The management currently carried out by homestay providers is to follow developments naturally and run as is according to current needs.

Internal and external influencing factors are included in the matrix so that the total value of internal is 3.3 while external factors are 3.08. The condition of the homestay is in cell 1 , which is very strong. In this case, the homestay can implement strategies for market penetration, market development, management, and product development. Thus, the four strategies identified in the SWOT analysis resulted in several strategies, namely: Improving the quality of homestay facilities and infrastructure, establishing and strengthening homestay institutions, designing integrated tourism packages, procuring digital system technology facilities, improving environmentally friendly village management, improving the quality of human resources for the http://ojs.unud.ac.id/index.php/eot homestay industry, strengthening the natural authenticity and traditions of local communities as Tete Batu icons, increasing the quality and diversification of tourist attractions, increasing awareness and creativity, empowering more varied communities, forming and launching pentahelix synergy.

\section{Suggestions}

a. For homestay providers:

The study recommends that the stakeholders immediately initiate the establishment of a homestay association in Tete Batu, there are a lot of needs that can be done together and homestay programs that must be ensured to run based on the local wisdom of the local community. With the existence of the Tete Batu Tourism Village homestay management unit, the capacity building and internal strengthening of the homestay providers will be able to run effectively and sustainably.

b. For people in the tourism area:

From an outsider's perspective, the community in it must maintain the authenticity of local traditions by preserving the environment and caring for their natural resources. The surrounding community must also be more proud and understand and also seize opportunities to be able to improve the local economy and 
potential and collaborate with homestay owners available in Tete Batu Tourism Village.

c. For the government:

So far, the village government seems to have not paid serious attention to the development of its tourist destinations. The village government should be proactive in facilitating homestays, which have been excellent. Therefore, the village government urges to make a spatial plan and governance of the Tete Batu tourist destination. Then the homestay management training by the East Lombok Tourism Office was still monotonous. Often the training materials and practical materials are the same and repeated so are the participants. The Tourism Office needs to arrange a form of training and mentoring that is directed, measured, and according to the needs of the latest homestay industry era.

\section{REFERENCES}

ASEAN. 2016. ASEAN Homestay Standard. Jakarta: The Asean Sectariat.

Cornell, D. 1997. Participatory Development: an Approach Sensitive to Class and Gender. Development in Practice 7 (3), 248-259.

David, Fred R. 2004. Manajemen Strategi, Konsep-Konsep. (Kreso Saroso, Pentj). Jakarta: Indeks Kelompok Gramedia.

Haywood, K.M. 1988. Responsible and Responsive Tourism Planning in The Community Tourism Management 9 (2), 105-108.

Hadiwijoyo, Suryo Sakti. 2012. Perencanaan Pariwisata Berbasis Masyarakat (Sebuah Pendekatan Konsep). Yogyakarta: Graha Ilmu.

Koentjaraningrat. 1981. Pengantar Ilmu Antropologi. Jakarta: Rineka Cipta.

Murphy, P.E. 1985. Tourism: a Community Approach. New York and London: Methuen.

NCIP (National Commission on Indigenous Peoples. 2000. Tribal Census as of 2000.

Neto, Frederico. 2003. A New Approach to Sustainable Tourism Development: Moving Beyond Environmental Protection. United Nations.

Noor, Any Ariany dan Pratiwi Dea Rizky. 2016. Konsep Pengembangan Pariwisata Berkelanjutan di Kampung Buyut Cipageran (kabuki) Kota Cimahi, Industrial Research, Workshop, National Seminar. Politeknik Negeri Bandung. July 2829.

Nurhidayati, Sri Indah. 2012. Pengembangan Agrowisata Berkelanjutan Berbasis Masyarakat di Kota Batu, Jawa Timur, Yogyakarta: Disertasi UGM.

Official Web Propinsi NTB. 2019. NTB Punya Modal Kuat Pulihkan Pariwisata.http://www.ntbprov.go.id /detailpost/ntb-punya-modal-kuatpulihkan-pariwisata diakses pada tanggal 21/03/2019. 
Profil Pemerintah Desa Tete Batu, Lombok Timur, Nusa Tenggara Barat, Indonesia. 2017. Diambil Pada Tanggal 4 Maret 2019 di Kantor Desa Tete Batu Jam 11.00

Pusat Penelitan Dan Pengembangan Kepariwisataan. 2011. Desa dan Budaya dalam Bingkai Pariwisata. Jakarta: Pusat Penelitian dan Pengembangan Kepariwisataan.

Rangkuti F. 2013. Analisis SWOT. Jakarta: PT. Gramedia Pusaka.

Siaran Pers Kemenpar. 2016. Menpar Berikan Penghargaan Kepada Pemenang Sayembara Desain Rumah Wisata Homestay. http://www.kemenpar.go.id/post/siar an-pers-menpar-berikanpenghargaan-kepada-pemenangsayembara-desain-rumah-wisatahomestay-n diakses pada tanggal 12 Desember 2019

Simmons David G. 1994. Tourism Management. Community Participant in Tourism Planning. Department of Parks, Recreational, Tourism, Lincoln University, PO Box 84, Canterbury, New Zealand.

Suansri, Potjana. 2003. Community Based Tourism Handbook. Thailand: Rest Project.

Terry, George R. 2000. Prinsip-Prinsip Manajemen. (edisi bahasa Indonesia), Bandung. PT Bumi Aksara.

UNEP \& UNWTO. 2005. Making Tourism More Sustainable: A Guide for Policy Makers. Spain: World Tourism Organization.

Weaver, D. and Lawton, 1. 2010. Tourism management. Fourt Edition. Australia: Jhon Wiley \& Sons Australia, Ltd. 